\title{
Traditional Islamic House (Ottoman House) Architecture, in Old Fatimid Cairo and Rosetta Cities, Egypt - An Example of Sustainable Architecture
}

\author{
Ahmed S. Attia \\ College of Architecture and Design, Jordan University of Science and Technology, Irbid 22110, Jordan
}

Corresponding Author Email: asattia@just.edu.jo

https://doi.org/10.18280/ijsdp.160812

Received: 26 October 2021

Accepted: 17 December 2021

\section{Keywords:}

Islamic context, natural environment, cultural environment, traditional Islamic house, Mashrabeiyah, wind catcher, Lowtechnology

\begin{abstract}
The unique Traditional Islamic architecture characterizes some cities in the Arab Republic of Egypt. The purpose of the study is to highlight the significance of the Traditional Islamic house design, architectural elements, and the use of low-technology in house construction concerning sustainable architecture, in Old Fatimid Cairo and Rosetta (Rashid) cities. The study's method includes a literature review; with an overview of the history, the urban form, and the Islamic house design and architectural elements influenced by the local Islamic context (natural and cultural environments). A field survey included: the selection of eleven examples, five from Old Fatimid Cairo city and six examples from Rosetta (Rashid) city representing the most famous houses including the different architectural elements, and analyzing its components, the house design, spatial organization, building materials, house elements, courtyard, Mashrabiyah, wind catchers, and the construction system. Moreover, a comparative study for the selected Islamic houses illustrates the contexts' impact on the house design. In conclusion, the study highlighted the significance of Islamic house design and low-technology in house design and construction, which could be considered sustainable architecture and developed in the form of advanced technology in the future.
\end{abstract}

\section{INTRODUCTION}

Egypt's located in the northeastern part of Africa and the southwestern part of Asia. The Sinai Desert links the two regions, it overlooks the Red Sea, the Mediterranean, the Suez Gulf, and the Aqaba Gulf. The Nile River is between Egypt and the south of the African continent, thus linking Asia and Africa. The current population of Egypt is 104 million and is considered one of Africa's most significant countries after Ethiopia and Nigeria. This site has the universe given Egypt a feature as it connects the east of the Arab-Asian world. The climate in Egypt is mainly a desert. Other than the north on the Mediterranean Sea, Egypt consists of four geographical regions, the River Nile Valley, the Delta, the Western Desert, the Eastern Desert, and the Sinai Peninsula [1]. It is different from cold to hot on the northern coast Mediterranean climate during winter (December to March), cold and wind, humidity with monsoon rains, and snowfall on the Sinai Mountains. Moreover, the summer months (May to August) are hot and very hot in the south of Egypt. Unique traditional architecture characterizes some of the Arab Republic of Egypt's cities, influenced by its natural and cultural environments (Islamic Context).

The study's method includes a literature review; with an overview of the climate, history, the urban form, and the Islamic house design and architectural elements influenced by the local Islamic context (natural and cultural environments) in Old Fatimid Cairo and Rosetta (Rashid) cities in Egypt (Figure 1) Egypt Map: Location of Cairo and Rosetta (Rashid) cities [1].

A field survey included: the selection of eleven examples,
Five from Old Fatimid Cairo city and six models from Rosetta (Rashid) city representing the most famous houses including the different architectural elements, and analyzing its components, the house design, spatial organization, building materials, house elements, courtyard, Mashrabiyah, wind catchers, and the construction system. Moreover, a comparative study for the selected Islamic houses illustrates the contexts' impact on the house design. In conclusion, the study highlighted the significance of Islamic house design and low-technology in house design and construction, which could be considered sustainable architecture and developed in the form of advanced technology in the future.

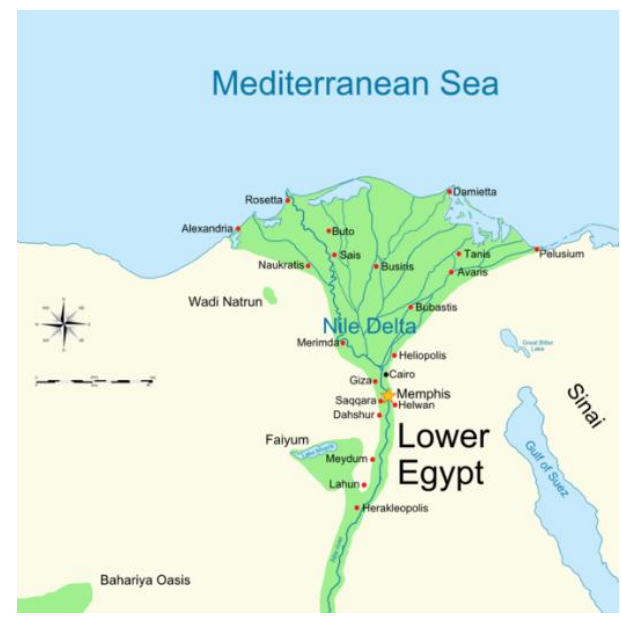

Figure 1. Egypt Map: Location of Cairo and Rosetta (Rashid) cities [1] 


\section{METHODOLOGY}

The study method includes literature review, site survey, analysis, and comparison for the selected Islamic house examples in Egypt's Old Fatimid Cairo and Rosetta (Rashid) cities.

Table 1. The selected examples of the traditional house in old Fatimid Cairo and Rosetta (Rashid) cities

\begin{tabular}{|c|c|c|}
\hline$\#$ & The City & House Name and Construction year \\
\hline 1 & \multirow{5}{*}{$\begin{array}{c}\text { Old } \\
\text { Fatimid } \\
\text { Cairo }\end{array}$} & $\begin{array}{l}\text { Gamal Al-Din Al-Zahabi House - } 1637 \\
\text { A.D./ } 1047 \text { A.H. }\end{array}$ \\
\hline 2 & & $\begin{array}{l}\text { Al-Kridilya House (located outside Old } \\
\text { Cairo) Gayer Anderson Museum - } 1630 \\
\text { A.D./ } 1041 \text { A.H. }\end{array}$ \\
\hline 3 & & $\begin{array}{l}\text { Al-Suhimy House. } 1648 \text { - } 1796 \text { A.D./ 1058- } \\
1211 \text { A. H. }\end{array}$ \\
\hline 4 & & $\begin{array}{l}\text { Abd Al-Rahman Al-Haraway House.1306 - } \\
1731 \text { A.D./ } 1144 \text { A. H. }\end{array}$ \\
\hline 5 & & $\begin{array}{l}\text { Zainab Khatun House - } 1808 \text { A.D./ before } \\
783 \text { A.H. }\end{array}$ \\
\hline 6 & \multirow{6}{*}{$\begin{array}{l}\text { Rosetta } \\
\text { (Rashid) }\end{array}$} & $\begin{array}{c}\text { Ramadan House - 18th Century A.D./ 12th. } \\
\text { A.H. }\end{array}$ \\
\hline 7 & & $\begin{array}{c}\text { Olwan House - 18th Century A.D./ 12th } \\
\text { Century A.H. }\end{array}$ \\
\hline 8 & & $\begin{array}{l}\text { Hassiba Ghazal House - } 1808 \text { A.D./ } 1223 \\
\text { A.H. }\end{array}$ \\
\hline 9 & & $\begin{array}{l}\text { Arab Killy House - 18th Century A.D / } \\
\text { 12th Century A.H. }\end{array}$ \\
\hline 10 & & $\begin{array}{l}\text { Abouhoum House - 18th Century A.D./ } \\
\text { 12th Century A.H. }\end{array}$ \\
\hline 11 & & $\begin{array}{c}\text { Othman Agha al-Amasyali House } 1808 \\
\text { A.D./ } 1223 \text { A.H. }\end{array}$ \\
\hline
\end{tabular}

The literature review included studying the history, city urban form, the Islamic house architecture, and elements in the two cities. Through field survey for the traditional houses examples, selected eleven examples; five from Old Fatimid Cairo city and six examples from Rosetta (Rashid) city representing the most famous houses including the different architectural elements, and analyzed its components; the house design, spatial organization, building materials, courtyard, Mashrabeiyah, wind catchers, study the function of each element and its relation to the urban context (Natural and cultural environments and sustainability. Table 1 shows the selected traditional house examples for the study.

A comparative study illustrates the contexts' impact (natural and cultural environments) on the Islamic house design.

Finally, the study highlighted the significance of the Islamic house design and its architectural elements, which influenced by the Islamic context (natural and cultural environments) and the use of low-technology in the house design and construction, could be considered as sustainable architecture and to be developed in the form of advanced technology in the future.

\section{OLD FATIMID CAIRO CITY URBAN AND ARCHITECTURAL CHARACTER}

Islamic Old Fatimid Cairo City, has founded in 969 A.D, and characterized by its condensed urban form and Islamic architectural style, for both residential, religious and commercial buildings; mosques, mausoleums, "Sabil and Kuttab" (schools and water fountains), "Khankah's" buildings (spiritual retreat) and "Wakkalah" (Inn and commercial building), Figure 2 shows Old Fatimid Cairo Map [2].

\subsection{Old Fatimid Cairo city urban and architectural character}

The ancient Fatimid old Cairo city's planning follows the Islamic city's planning, with urban fabric interspersed with narrow paths. The house buildings are constructed of stone and consists of two or three floors, the openings of its windows covered with "Mashrabiyah" (wooden lattice window box) and characterized by its projections providing shades projecting pedestrians from the sun (Figure 3. a, b, c) shows different outside views of the Islamic House.

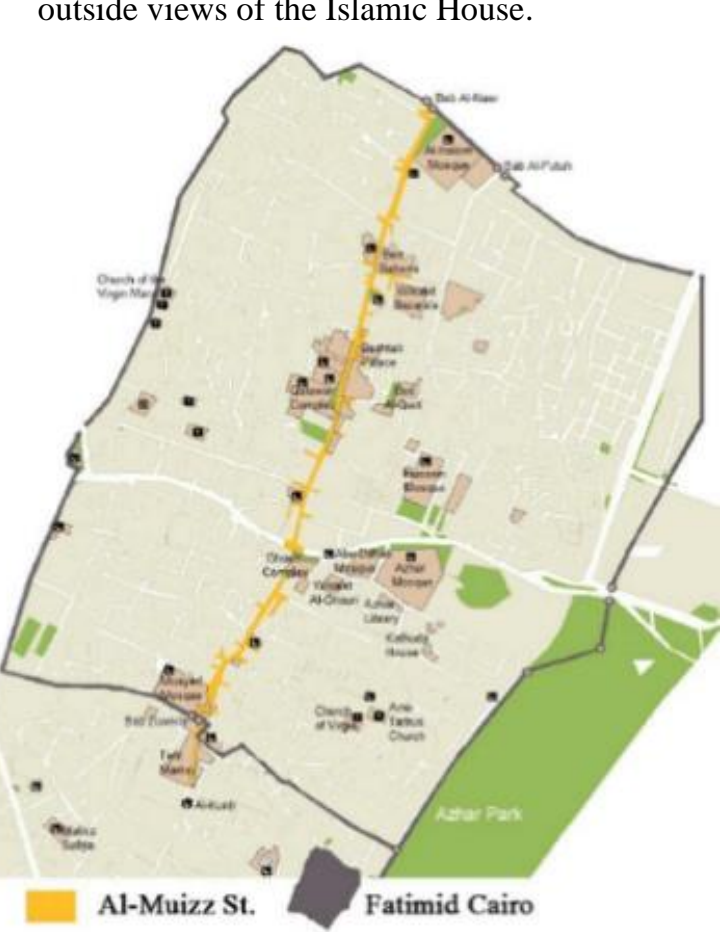

Figure 2. Old Fatimid Cairo map [3] 
(Figure $4 \mathrm{a}, \mathrm{b}$ ) shows the elements of the Islamic houses in Old Fatimid, Cairo. In addition to residential buildings, the city also includes religious buildings, mosques giving a unique flavor to the city by its minarets and domes. Also, to other types of buildings, "Sabil and Kuttab" (schools and water fountains), Commercial buildings, souks and "Wakkalah" buildings (Inn and commercial building), and public baths are marked by squares in front of the large mosque. Domes and minarets distinguish their religious buildings.

In 1979 UNESCO declared Cairo a world cultural heritage site and considered "one of the world's oldest Islamic cities, with famous mosques, madrassas, mausoleums, Sabil and Kuttab (Madrassa and water fountains)" [4].

\subsection{Traditional Islamic house, the design and particular organization in Old Fatimid Cairo city}

Abd Al-Rahman Al-Haraway house adjacent to the AlAzhar Mosque and constructed in 1731 A.D. It consists of central courtyards and a water fountain, where the house elements overlook the courtyard, and it is considered open toward the inside, keeps the air cold in the house, and ensures privacy. The stone walls characterize the houses and covered windows with "Mashrabiyah" and projections overlooking the narrow paths.

The ground floor contains "Maqa'ad" (the seat for foreign visitors), while the first floor contains the "Takhtaboush" living room for family and women). Also, to the "Qa'aa" (a rectangular hall is overlooking two areas called Iwan). The "Iwan" is an area surrounded by walls on its three sides and overlooks the "Durka'a" (the central hall). The ceiling of the "Qa'aa" rises for two or three floors, where it overlooks the "Qa'aa,"; and covered with a wooden ceiling contains beautiful ornaments and topped by a lantern called "Shakshekhah" (clearstory) providing natural lighting and continuous natural ventilation with cold air. Also, a cistern for drinking water is available in most houses (Figure $5 \mathrm{a}, \mathrm{b}, \mathrm{c}$ ) shows Abd AlRahman Al-Haraway House elements (Figure 6 a, b, c, d) shows Zainab Khatun House elements [5, 6].

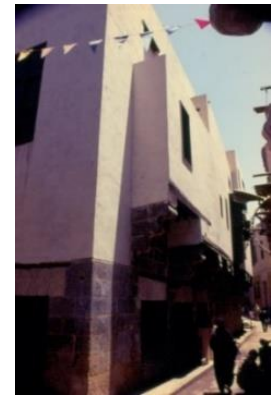

a. Gamal Al-Din Al-Zahabi House 1637 A.D./ 1047 A.H.

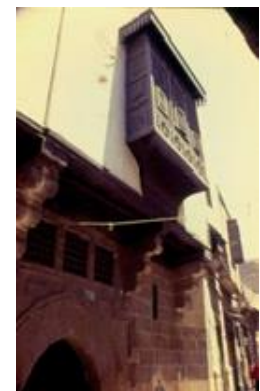

b. Gamal Al-Din Al-Zahabi House. 1637 A.D./ 1047 A.H

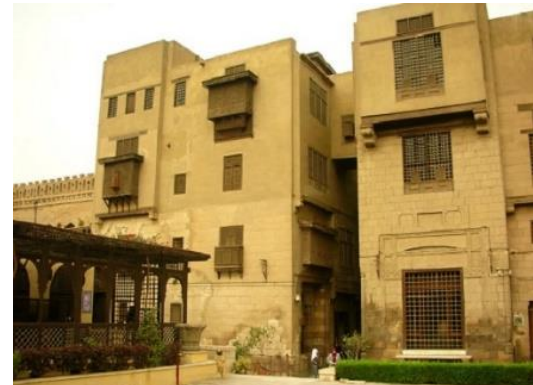

c. Al-Kridilya House (located outside Old Cairo) Gayer Anderson Museum. 1630 A.D./ 1041 A.H

Figure 3. Different outside views of the Islamic House in Old Fatimid, Cairo

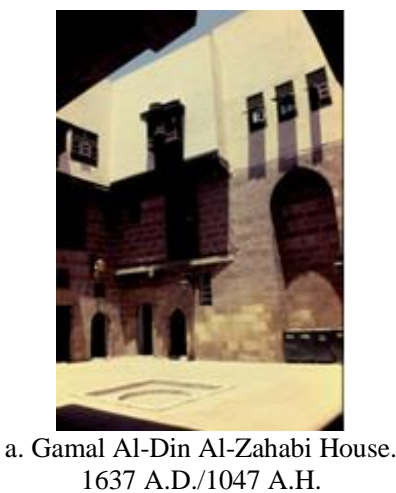

1637 A.D./1047 A.H.

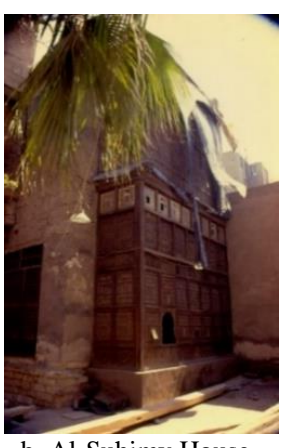

b. Al-Suhimy House. 1648 - 1796 A.D./ 1058-1211 A. H.

Figure 4. The elements of the Islamic houses in Old Fatimid, Cairo

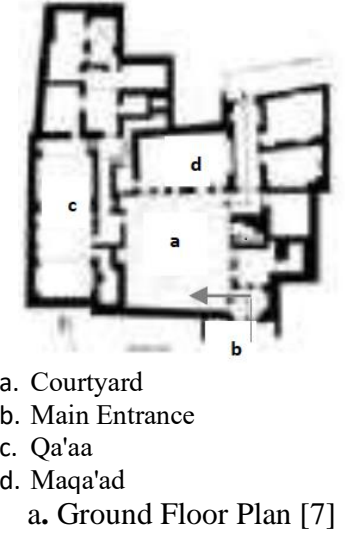

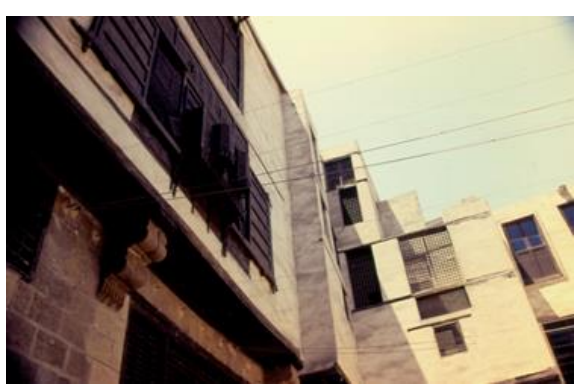

b. Façade overlooking the courtyard

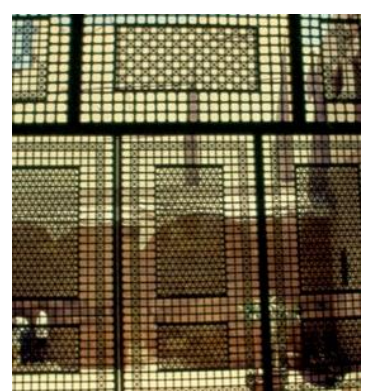

c. Mashrabiyah

Figure 5. Abd Al-Rahman Al-Haraway House.1306-1731 A.D./ 1144 A. H. 


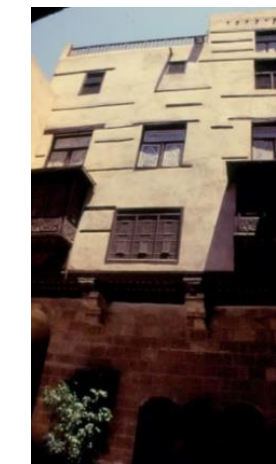

a. External Façade

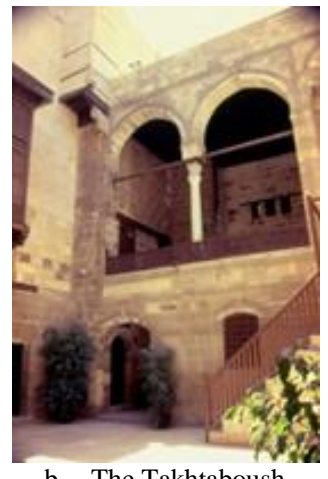

b. The Takhtaboush

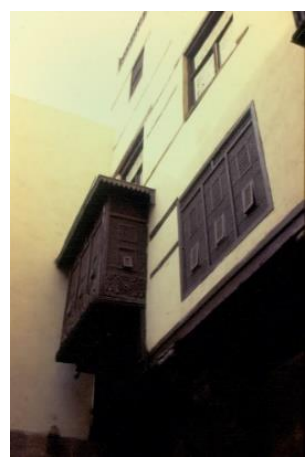

c. The Mashrabiyah

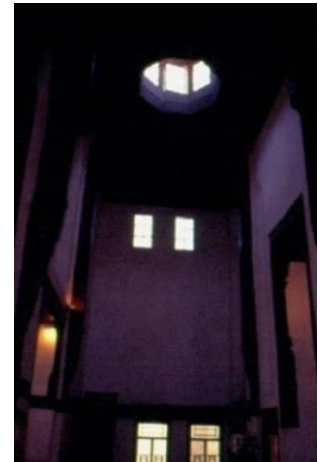

d. The Shukhikhak (skylight)

Figure 6. Zainab Khatoun House.1808 A.D./ 783 A. H.

\section{ROSETTA (RASHID) CITY LOCATION AND HISTORICAL SIGNIFICANCES}

Rosetta (Rashid) city is situated on the Nile River's western side (Rosetta Branch), where the river flows ahead of the Mediterranean Sea and far $65 \mathrm{~km}$ northeast of Alexandria. Unique architecture characterizes Rosetta (Rashid) city, where it contains many Islamic residential and religious buildings (mosques) and public buildings (Caravansary, public baths (Figure 7) Old Rosetta (Rashid) City Map. Moreover, the urban heritage streets have some common architectural characteristics regarding the style and history, diversity of time, and the uniqueness of the architecture and urban form [8].

\subsection{Rosetta city (Rashid) urban form}

The importance of the Pharaonic era was called Bolbotine and named Rosetta/Rashid since Amr ibn al-As' opening to Egypt in 21 A.H./64 A.D. The city became important after discovering Rashid's Stone during the French campaign in 1799 [9]. The city's planning follows Islamic city planning; the city's urban fabric is a form of a compacted urban tissue interspersed with paths and consists of religious buildings (mosques), "Caravansary," commercial baths, and residential buildings.

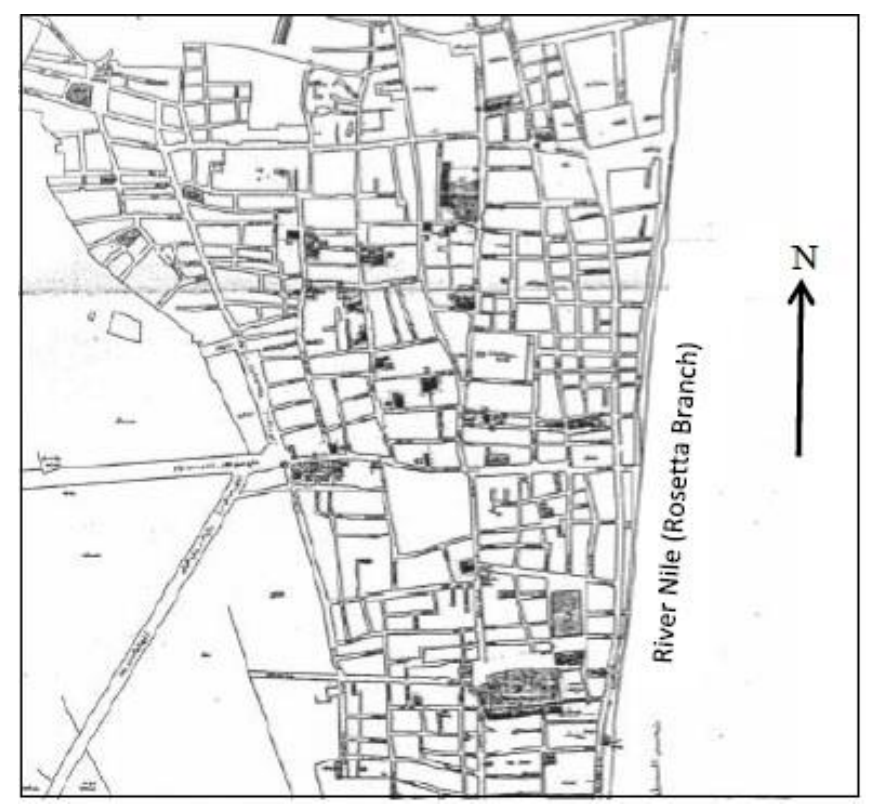

Figure 7. Old Rosetta (Rashid) City Map [7]
Egyptian Ministry of Antiquities is currently preparing a file to submit to the UNESCO World Heritage Centre, for the city's world heritage list, according to data prepared in 2003 [10]. "The city contains many Islamic heritage sites, which ran from 52 in 1193 and 37 in 2005 to 22 houses, 12 mosques, a public bath, a mill, and the city gates" [11].

The city faces problems due to the population's decreation and immigration to large cities, Cairo and Alexandria, demolishing many historical buildings and replacing them with new constructions. Moreover, the urban fabric is affected by its relation to the River Nile [12].

In 2010, the Rosetta Governorate set a development plan concept to develop the historical city core, as an open museum, with the following as pillars for the urban revitalization:

1. Transfer the main streets as pedestrian paths.

2. Development of the public plazas as a public museum.

3. Construct a shopping center outside the city's historical core [13].

\subsection{Traditional Islamic house the design and unique organization in Rosetta (Rashid) city}

Residential buildings' heights vary from 3-4 floors built of red and black molded mud bricks, called "Grout Bricks," with white gypsum as an adhesive for brick courses. The use of corbels to support projected upper floors and "Mashrabiyah" (wooden lattice window box) for openings of windows, provides lighting, continuous ventilation, and privacy (Figure $8 \mathrm{a}, \mathrm{b}, \mathrm{c}, \mathrm{d})$ shows the Islamic house architectural character (wooden Mashrabiyah and wooden lattice) Rosetta (Rashid) city.

The construction and building materials consist of a bearing wall constructed of molded mud bricks and wooden corbels to carry the upper floors' protrusions with a column in the outer corners of the house and Wooden ceilings.

The house ornaments consisted of the red and black molded mud bricks, called "Grout Bricks," with white gypsum as an adhesive for brick courses and the facades decorated with "Mashrabiyah" characterized with three surfaces, and carried on two supports for the first time in the houses of Al-Kanadily.

The wooden lattice windows consist of small pieces interlocked without nails using ivory and shell grafts and interlock fillings in beautiful geometric shapes in interior decorations. Also, Quranic inscriptions or writings containing the building's name and the construction date appeared in ornamentation shapes above the Sabil metal window (Figure 9 $\mathrm{a}, \mathrm{b}, \mathrm{c})$ shows different window treatments with wooden Mashrabiyah boxes and wooden lattice. 


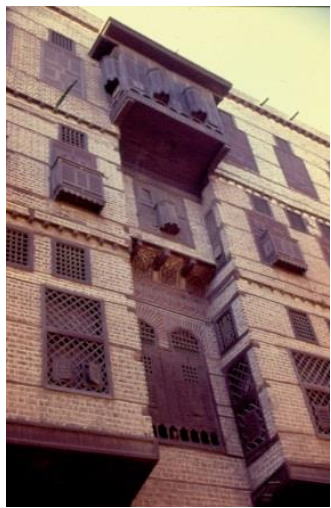

a. Ramadan House

$18^{\text {th }}$ c. A.D./ $12^{\text {th }}$ c.A.H

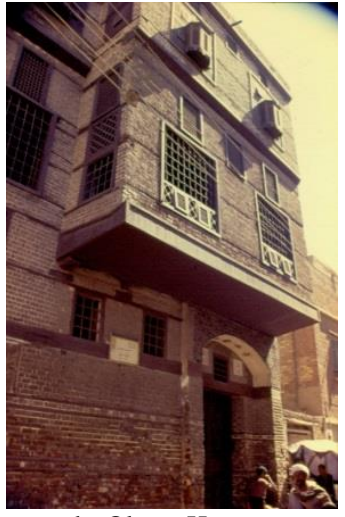

b. Olwan House $18^{\text {th }}$ c. A.D./ $12^{\text {th }}$ c.A.H

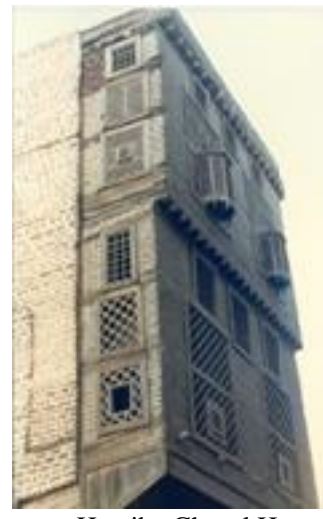

c. Hassiba Ghazal House 1808 A.D./ 1223 A.H

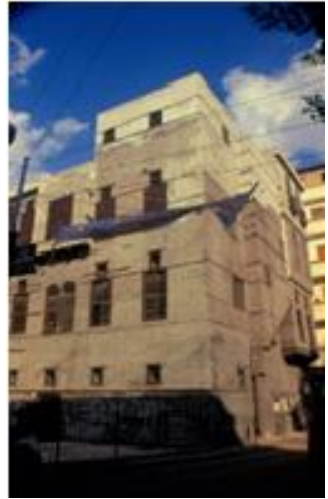

d. Arab Killy House $18^{\text {th }}$ c. A.D $/ 12^{\text {th }}$ c.A.H

Figure 8. Islamic House Architectural Character Rosetta (Rashid) city (wooden Mashrabiyah and wooden lattice in the Islamic House Rosetta (Rashid) City

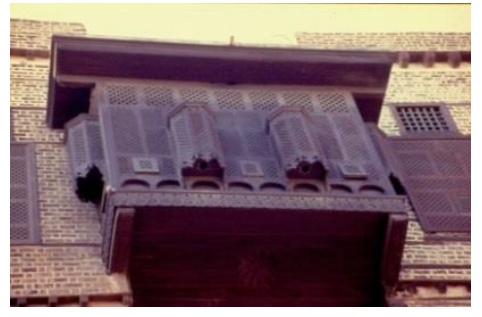

e. Ramadan House $18^{\text {th }}$ c. A.D./ $12^{\text {th }}$ c.A.H

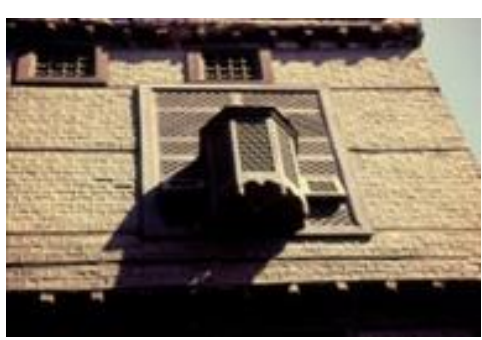

f. Abouhoum House $18^{\text {th }}$ c. A.D./ $12^{\text {th }}$ c.A.H

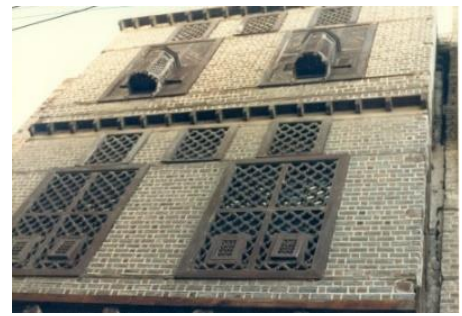

g. Hassiba Ghazal House 1808 A.D./ 1223 A.H.

Figure 9. Different Types of windows treatments (with wooden Mashrabiyah and wooden lattice, Islamic House Rosetta (Rashid) City

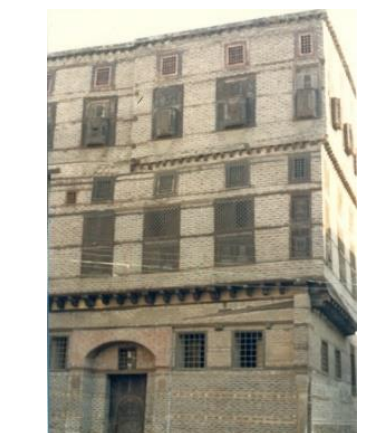

a. General house view

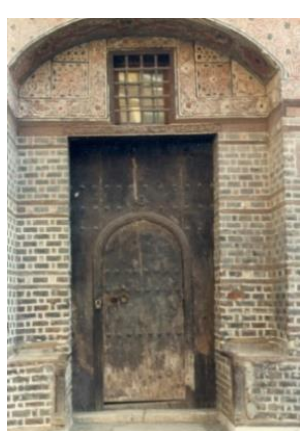

b. House main entrance. Source: Author

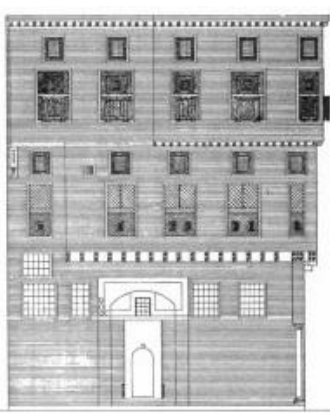

c. North Elevation [6].

Figure 10. General views of Othman Agha al-Amasyali House 1808 A.D./ 1223 A.H., Rosetta (Rashid) City

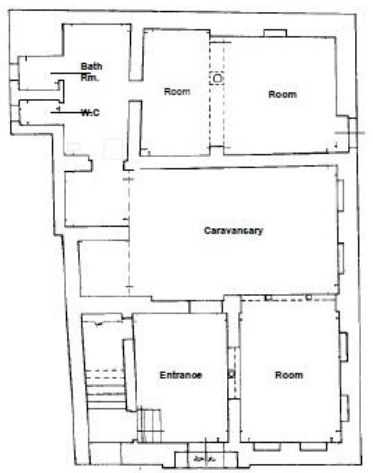

Ground floor plan

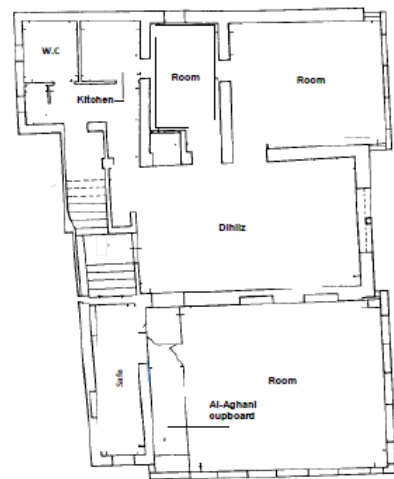

First-floor plan

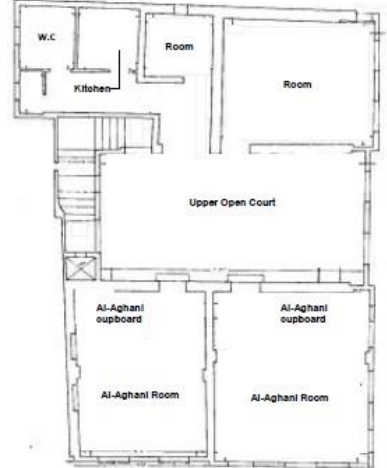

Second Floor Plan

Figure 11. Spatial organization of Othman Agha al-Amasyali House 1808 A.D./ 1223 A.H., Rosetta (Rashid) City [6] 


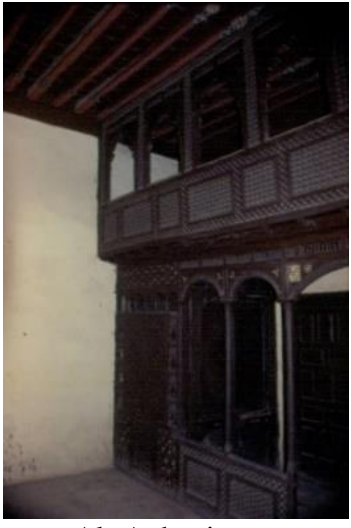

a. Al- Aghani room

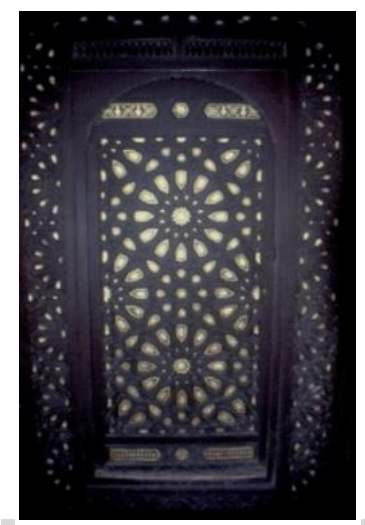

b. Al-Aghani cupboard

Al-Amasyali House, 1808 A.D./ 1223 A.H.

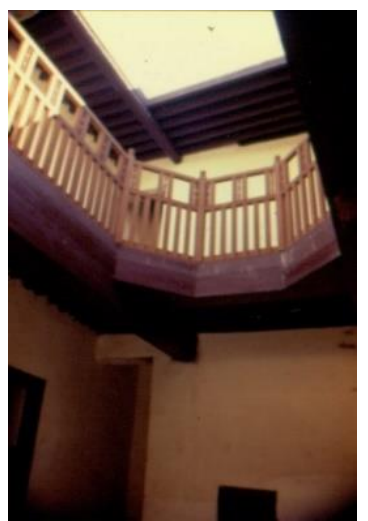

c. Upper opened floor

Ramadan House, $18^{\text {th }}$ c. A.D./ $12^{\text {th }}$ c.A.H

Figure 12. The Islamic house in Rosetta (Rashid), Different elements and ornaments

The house consists of three floors, characterized by "caravansary" or stores for storage of goods and as a place for the expatriate merchants' house, and stable allocated to the house owners and guests with a door opened at the side street (Figure 10 a, b, c) shows general views of Othman Agha alAmasyali house. The "Sabil" overlooks the public street and contains a metal window mesh preceded by a marble water basin and a water tank beneath the house.

The first floor is reserved for men and has an independent door centralized with the main hall called "Durka'a" surrounded by several rooms, where one of these rooms the main living room called "Dihliz" to ensure privacy (Figure 11) illustrates the Spatial organization of Othman Agha alAmasyali house.

The second floor is for the ladies and is called "Al-Hadeer" (place for sleeping), and rooms around the main hall called" Iwan" the openings contain stained colored glass, the ceiling using groined arches at the ground floor and wooden ceiling on the upper floors. Moreover, it contains a central room called the "Al-Aghani" song used by ladies to hear music and watch music bands. It also includes wooden cabinets decorated with ivory and row $[5,11,14]$. The upper floor contains an open space toward the sky overlooking the north side for use during summer (Figure 12) shows (a) "Al- Aghani room," and (b) the Al-Aghani cupboard at Al-Amasyali House, and (b) the Upper opened floor at Ramadan House [5, 14].

\section{COMPARISON BETWEEN THE TRADITIONAL ISLAMIC HOUSE (OTTOMAN HOUSE) IN OLD FATIMID CAIRO AND ROSETTA (RASHID) CITIES}

\subsection{The house design and climate}

The construction of Cairo's houses from stone available in the desert from the adjacent mountain areas to the city, while Rosetta (Rashid) is located in the Rosetta Nile river branch; thus, the houses constructed from mud bricks available from the river (Rashid Brach) are available to the city located on the Nile river.

The temperature in Cairo City is higher than in Rosetta City and dry. The house elements overlook a central courtyard to provide cold air and privacy. Due to Rosetta's moderate temperature (Rashid), the house design does not contain a courtyard, and it contains open space at the top level, oriented toward the north direction. During the summer months (May to August), Cairo's average high temperature is $32.0^{\circ} \mathrm{C}-34.7^{\circ} \mathrm{C}$, while Rosetta (Rashid) city is $27.2^{\circ} \mathrm{C}-31.5^{\circ} \mathrm{C}$.

Window openings in both houses in Cairo and Rosetta (Rashid) cities, covered by "Mashrabiyah" (wooden lattice widow), provide cold air and privacy. Also, the houses in Rosetta city contain shops and stores, as most city residents work in trade; this is due to the city's location as a port in the River Nile and the Mediterranean Sea.

The trade areas are isolated from Old Cairo's residential quarters and particular commercial and trade buildings. The trade areas in Old Cairo, separated from the residential areas and allocated in private buildings called Wakkalah. In general, the mosques' buildings with their minarets and domes characterize the city. Because Rosetta city is considered a port according to its location on the river Nile and the Mediterranean Sea, and, as most of the residents in Rosetta city working in the trade-in trade because it is a port on the River Tail and the Mediterranean Sea, the majority of the houses contain shops on the ground floor. Table 2 comparison between the traditional Islamic house (Ottoman House) in Rosetta (Rashid) and Old Fatimid Cairo Cities illustrates the similarities and differences in construction systems, building material, and house elements.

\subsection{Islamic Architecture and sustainability}

The idea of sustainability in Islamic architecture is not new to Islam, it existed for centuries and associated with the Holly Quran and Hadeeth, where it formed the framework of how to ecological, biodiversity, and communicate with the surrounding nature [15].

The idea of sustainability from an Islamic perspective includes meeting social and economic needs that must be interlink man and the environment; ecological, biodiversity, and utility values for humankind both as spiritual substance and material resources, which applied in both city planning and the house design reflected that (Figure 13) [16]. Moreover, the house design is considered sustainable architecture. The house design and unique organization fulfill the ethical, social, and religious traditions. At the same time, the architectural elements, inner courts, Mashrabeiyah, windcatchers fulfill the climate requirements regarding human comfort and energy consumption. 
Table 2. Comparison between the traditional Islamic house (Ottoman House) in Rosetta (Rashid) and Old Fatimid Cairo Cities

\begin{tabular}{|c|c|c|c|c|c|c|c|c|c|c|c|c|c|}
\hline \multirow{3}{*}{ \# } & \multirow{3}{*}{$\begin{array}{c}\text { The House Location } \\
\text { Old Fatimid Cairo/ } \\
\text { Rosetta (Rashid) } \\
\text { Cities }\end{array}$} & \multicolumn{5}{|c|}{ Construction System \& Building Materials } & \multicolumn{6}{|c|}{ The House Elements } & \multirow{3}{*}{ Remarks } \\
\hline & & \multicolumn{2}{|c|}{$\begin{array}{l}\text { Construction } \\
\text { System }\end{array}$} & \multicolumn{3}{|c|}{ Building Materials } & \multicolumn{2}{|c|}{$\begin{array}{c}\text { Courtyard/ } \\
\text { Upper } \\
\text { terrace }\end{array}$} & \multicolumn{2}{|c|}{ Mashrabiyah } & \multicolumn{2}{|c|}{$\begin{array}{c}\text { Wind } \\
\text { Catchers }\end{array}$} & \\
\hline & & $\begin{array}{c}\text { Bearing } \\
\text { Walls }\end{array}$ & $\begin{array}{c}\text { Other } \\
\text { System }\end{array}$ & Stone & $\begin{array}{c}\text { Mud } \\
\text { Brick }\end{array}$ & $\begin{array}{c}\text { Wood } \\
\text { Ceiling }\end{array}$ & yes & No & yes & No & yes & No & \\
\hline 1 & $\begin{array}{l}\text { The Islamic House } \\
\text { in } \\
\text { Old Fatimid Cairo } \\
\text { City }\end{array}$ & $\mathrm{X}$ & & $\mathrm{X}$ & & $\mathrm{X}$ & $\mathrm{X}$ & & $\mathrm{X}$ & & $\mathrm{X}$ & & $\begin{array}{c}\text { Ornaments consist } \\
\text { of colored stones, } \\
\text { cornices, } \\
\text { stalactites, and } \\
\text { ornaments in the } \\
\text { wooden ceiling. }\end{array}$ \\
\hline 2 & $\begin{array}{c}\text { The Islamic House } \\
\text { in } \\
\text { Rosetta (Rashid) } \\
\text { City }\end{array}$ & $\mathrm{X}$ & & & $\mathrm{X}$ & $\mathrm{X}$ & & $X$ & $X$ & & & $X$ & $\begin{array}{l}\text { Ornaments consist } \\
\text { of colored mud } \\
\text { bricks and } \\
\text { stalactites as } \\
\text { ornaments at the } \\
\text { house entrance. }\end{array}$ \\
\hline
\end{tabular}

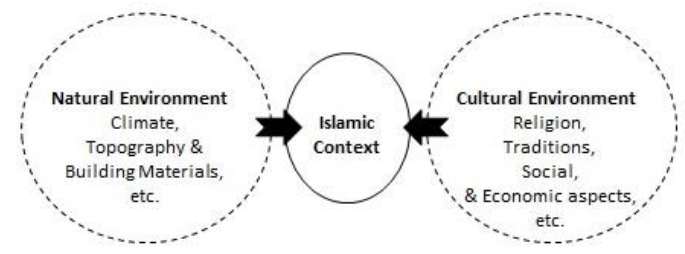

Figure 13. The Islamic context with sustainability

\section{THE TRADITIONAL ARCHITECTURE TECHNIQUES AND THEIR APPLICATION IN CONTEMPORARY ARCHITECTURE}

\subsection{Maslar city, Dubai, UAE}

Masdar City in Dubai, United Arab Emirates total area of

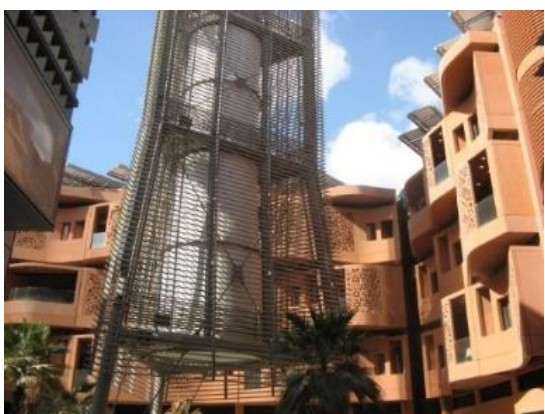

a. Wind Catcher
$17 \mathrm{~km}^{2}$, is considered a sustainable architecture. The project applied many elements of Islamic architecture to meet the local climate; the window openings similar to the Mashrabiyah in the Islamic house providing ventilation and privacy, the wind catchers similar to (Malkaf) for cooling and ventilation, and the outer courtyards offer shades, the building is certified by LEED (Leadership in Energy and Environmental Design) (Figure 14 a, b) $[17,18]$.

\subsection{Qatar University, Doha, Qatar}

The university was established in 1973 with a total area of 2000 acres, with 150 students, in 2006 the number of students reached 7660 students, the university campus planning and the design of its buildings followed the Islamic architecture, as it contains several elements; the wind catchers for cooling and ventilation in addition to the courtyards (Figure $15 \mathrm{a}, \mathrm{b})[17$, 19].

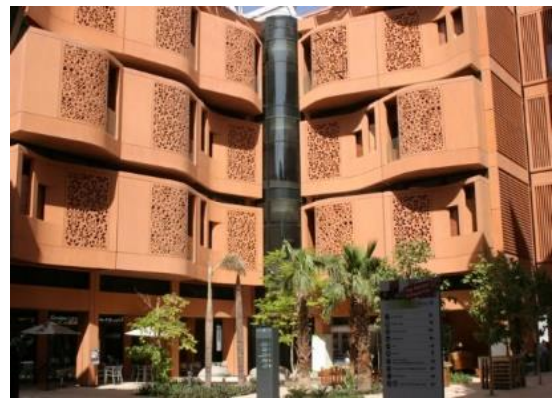

b.Window openings

Figure 14. Masdar city, Dubai, UAE [18]

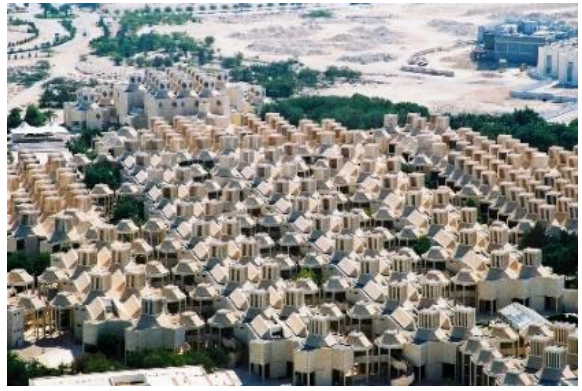

a.University Campus, general view

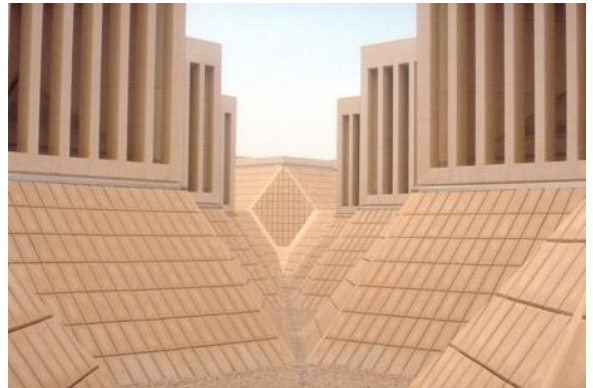

b. Wind Catcher

Figure 15. Qatar University, Doha, Qatar [19] 


\section{CONCLUSION}

Islamic context impacts on the Islamic house design, in terms of natural and cultural environments, especially the geographical location, and the Islamic traditions, have affected the design of the Islamic house, both in terms of climate, the available building materials, the social aspects of customs, traditions, and the economic aspects.

The hot, dry climate in Old Fatimid Cairo city led to an open courtyard and opened the house to the interior to provide moist air and privacy. Due to Rosetta's (Rashid) climate, the house is open outside and uses an open terrace on the upper floororiented toward the north instead of the courtyard.

Houses in Cairo city were built of available stones from the areas around the city, while in Rosetta (Rashid), located on the bank of the Nile river (Rosetta Branch), it uses mud bricks. The "Mashrabiyah" was also used to cover the window openings in both houses in Old Fatimid Cairo and Rosetta (Rashid) cities to provide wet air and prevent vision from the outside, providing privacy.

Cairo houses did not include retail stores, while some retail stores found on the ground floors of some houses in Rosetta (Rashid) city, as many of city residents' trade and they are more open as the city is considered a harbor according to its location on the Nile River and the Mediterranean Sea.

As previously discussed, context, natural, and cultural environments strongly influence the Islamic Traditional house design and architecture in Egyptian cities. Moreover, natural building materials (Stone and Wood, the house design and architecture elements) are considered an example of sustainable architecture.

The house spatial organization and its elements; the courtyard, Mashrabeiyah, wind catchers, and the use of lowtechnology in house construction system as thick bearing walls provide energy efficiency and good indoor environment quality. Moreover, the Mashrabeiyah works as a curtain to provide both privacy for house residents and cross ventilation to the indoor environment, and the use of natural building material with zero-carbon emission. In the future, apply the low-technology used in hose construction systems in the form of advanced technology.

\section{REFERENCES}

[1] Egypt Map.

www.google.com/search?q=Egypt+map\&tbm=isch\&so urce=iu\&ictx $=1 \&$ fir $=6 \mathrm{JmYkxtlLXZHGM} \% 252 \mathrm{C} 9$ Qyjts 1UBcOfLM\%252C_\%253BqsETAEwSIZTVRM\%252 CiauesbgOscgf3M\%252C_\%253BmT15f7-

\#imgrc=p1 mOtfguQ1 KTkM\&imgdii=OuCw5IOSvIiOH M, accessed on Sep. 12, 2021.

[2] World Climate Guide. (2020)

https://www.climatestotravel.com/climate/egypt, accessed on Oct. 14, 2020.

[3] Mahgoub, M.H. (2013). Urban morphology impact microclimate of the Fatimid city, Cairo, Egypt. International Conference on "Changing Cities": Spatial, morphological, formal \& socio-economic dimensions Skiathos Island, Greece. https://www.researchgate.net/publication/262860822_U rban_morphology_impact_on_microclimate_of_the_Fat imid_city_Cairo_Egyp, accessed on Oct. 14, 2020.

[4] UNESCO. (2020). United Nations Educational,
Scientific, and Cultural Organization. Urban Regeneration for Historic Cairo. https://whc.unesco.org/en/historic-cairo-project/, accessed on Oct. 14, 2020.

[5] Ibrahim, A.M. (1990). Architectural design and urban planning foundations - Cairo as a state research. The Centre of Planning and Architectural Studies (CAPS), Cairo, Egypt. www.noor-book.com/book/review/330648.

[6] Lamei, S.M. (1984). Islamic Architectural Heritage in Egypt. Dar Al-Nahda Al-Arabia, Beirut, Lebanon. (In Arabic). www.ciah.biz/content/prof-lamei-publications.

[7] Abdelkader, R., Park, J.H. (2020). Spatial principal of traditional Cairene courtyard houses in Cairo. Journal of Asian Architecture and Building Engineering, 17(2): 245-252. htpps://doi.org/10.3130/jaabe.17.245

[8] Ragheb, R.A., Naguib, I.M. (2018). Reinvestment of the urban context in Historic cities: The case study of El Sheik Kandil Street, Rosetta, Egypt. ICSUSDA 2018: 20th Int. Conf. on Sustainable Urban Street Design and Assessment. Vienna, Austria. www.researchgate.net/publication/330831919_Reinvest ment_of_the_Urban_Context_in_Historic_Cities_The_ Case_Study_of_El_Sheikh_Kandil_Street_Rosetta_Egy pt, accessed on Sep. 12, 2021.

[9] Al-Alfy, A.M.S. (1985). Rosetta Monuments. Cairo Egyptian Antiquities Organization Press (In Arabic). www.abebooks.com/Rosetta-Monuments-Amal-MSafwat-El-Alfy/12369423171/bd.

[10] UNESCO. (2003). Historic quarters and monuments of Rosetta I Rashid. www.worldheritagesite.org/tentative/id/1831\#: :text=H istoric $\% 20$ quarters $\% 20$ and $\% 20$ monuments $\% 20$ of $\% 20 \mathrm{R}$ osetta\%2FRachid $\% 20$ is $\% 20$ part,can $\% 20$ be $\% 20$ seen $\% 2$ 0in\%20the\%20remaining\%20Ottomanstyle\%20mansions, accessed on Nov. 9, 2020.

[11] Elsorady, D.A. (2012). Heritage conservation in Rosetta (Rashid): A tool for community improvement and development. Cities, 29(6): 379-388. https://doi.org/10.1016/j.cities.2011.11.013

[12] Hegazi, Y.S., Fouda, M. (2019). Re-imaging Rosetta historic core through Space Syntax. Archnet-IJAR: International Journal of Architectural Research, 13(3): 645-669. https://doi.org/10.1108/ARCH-05-2019-0109

[13] Aldiasty, A., Sabry., Y., El-Khouly, T. (2021). Using space syntax and TOPSIS to evaluate the conservation of urban heritage sites for possible UNESCO listing the case study of the historic center of Rosetta, Egypt. Ain Shams Engineering Journal, 12(4). https://doi.org/10.1016/j.asej.2021.04.017

[14] El-Hadidy, M., Abd Al-Aleem, F., Darwish, M., Abu AlAzaiem, M. (1985). Restoration and development project of the Islamic city Rasheed (Rosetta). Archeological Review, (In Arabic). https://www.cpasegypt.com/pdf/egyptian/20.pdf, accessed Oct. 14, 2020.

[15] Abdussamad, S. (2021). Islamic perspectives: An alternative to the existing model of social sustainability in architecture. A CIS Student Research Journal, Vol. 2021(3): 1-29.

[16] Sarkawi, A., A, Abdullah, A, and Dali, N. Md. (2016). The concept of sustainability from Islamic perspectives. International Journal of Business and Law, 9(5): 112-116.

[17] Attia, A.S. (2019). Traditional sustainable architecture techniques and its applications in contemporary architecture: Case studies of the Islamic house in Fatimid 
Old Cairo and Sana'a Cities in Egypt and Yemen. World Academy of Science, Engineering and Technology. International Journal of Civil and Environmental Engineering, $\quad$ 13(5): 266-271. https://doi.org/10.5281/zenodo.3298687

[18] Masdar City,

Dubai. www.google.com/search?q=masdar+city\&tbm=isch\&so urce=iu\&ictx $=1 \&$ fir, accessed on Sep. 12, 2021.

[19] Qatar University Campus. www.archnet.org/sites/288?media_content_id=25264, accessed Sep. 12, 2021. 